\title{
Financial doubts over future of chimp lab
}

[WASHINGTON] The laboratory housing the world's largest domesticated chimpanzee colony may be near financial collapse, animal rights activists are claiming.

The Coulston Foundation (TCF) of Alamogordo, New Mexico, has lost two contracts to house HIV-infected chimps and conduct AIDS vaccine research on them. The National Institutes of Health (NIH) contracts brought the facility about $\$ 10$ million over the past six years.

Many of the TCF's 620 chimpanzees were infected early in the AIDS epidemic, when scientists were seeking models for studying the disease. But they are used less now because, while infectable with HIV, they do not get sick from the disease.

The foundation denies being in financial peril, saying the loss of the NIH contracts is due to a change in the bidding process, and that it intends to bid for a new contract.

But In Defense of Animals (IDA), a Californian group that opposes the use of animals in research, claims that the lost contracts could tilt the $\$ 10.5$ million lab towards financial failure. "The loss of these NIH funds could spell the beginning of the end for TCF," says Suzanne Roy, IDA's programme director.

The group alleges that the lab's private sources of funding - about half its revenues, according to the foundation -- are drying up. TCF laid off 20 employees in November.

If the lab fails it would exacerbate a difficult situation in which a surplus of US research chimps - expensive to care for and used less and less by scientists - need housing. The National Research Council recommended in 1997 that the NIH establish a \$7 million-ayear programme to care for the government's approximately 1,000 chimps (see Nature 388, $218 ; 1997)$. But this has not been done.

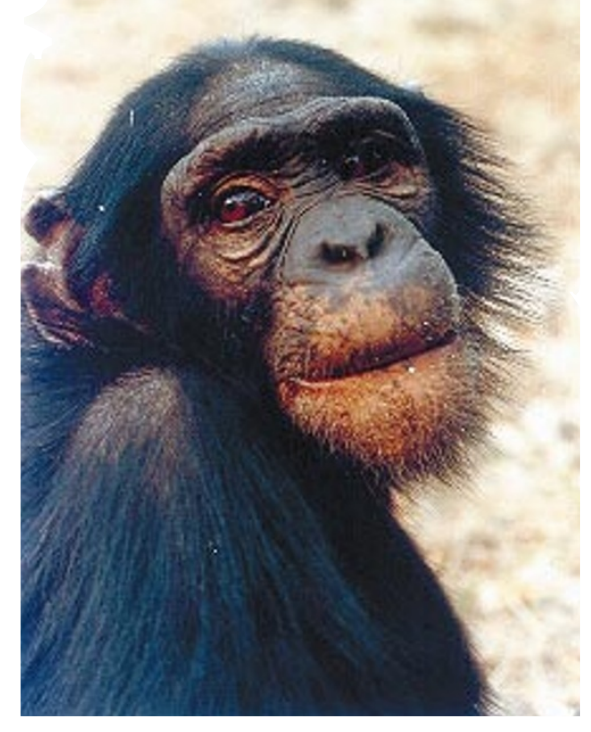

Out of contract: chimps are used less now by scientists because they do not develop AIDS.

Don McKinney, a spokesman for TCF, says that NIH did not renew the government contracts because it is moving to a competitive bidding process. "We have the right to bid on them again and we fully intend to."

McKinney declines to discuss the lab's private funding, saying that supporters are harrassed by activists if they are identified. He says the activists, whom he describes as "gangsters", have been "trying to ring our death knell for several years. Obviously they weren't too accurate." An NIH spokesman says that the contracts were not cut off because of problems: "It's just that they expired."

The IDA has been investigating TCF for five years, and alleges chronic neglect of the lab's chimps. The group has been vindicated at least in part by three formal complaints

\section{Japan plans CDNA hunt for disease genes}

[токуо] The University of Tokyo and 12 Japanese companies have started a joint initiative to sequence and analyse full-length human complementary DNA (cDNA) to discover patentable genes that will contribute to the understanding of diseases.

The project is intended to develop new technologies in drug development, bioinformatics and gene therapy. It will receive $¥ 2.5$ billion (US\$208 million) in this fiscal year, which began on 1 April.

Researchers from the university's Institute of Medical Sciences will provide the companies with cDNAs from various tissues, including cancerous tissues from liver, lung and stomach, and those linked to neurological and immunological diseases.

The companies will carry out DNA base sequencing and analysis of proteins, with an aim of discovering patentable genes for medical use and research. They plan to sequence 7,500 cDNA clones by next March.

The project involves companies such as Hitachi, Daiichi Pharmaceuticals, Kyowa Hakko and Otsuka Pharmaceutical Co., and is funded by the New Energy and Industrial Technology Development Organization, which is affiliated to the Ministry of International Trade and Industry.

The move is in line with government efforts to commercialize biotechnology research. In January, five government bodies launched a 10-year programme to expand 25-fold Japan`s biotechnology market (see Nature 397, 554; 1999).

The programme is expected to create a market worth $¥ 25$ trillion and to help create up to 80,000 jobs by 2010 . Asako Saegusa issued by the United States Department of Agriculture (USDA), charging that the lab has violated the Animal Welfare Act. The most recent was issued in February.

USDA inspectors found the lab dirty, infested and without adequate ventilation, adequate protection from extreme temperatures or adequate removal of animal and food wastes. They documented the deaths of chimpanzees from inadequate veterinary care, including failure to treat an animal for shock before surgery after it was attacked by another chimp, and failure to monitor it adequately after surgery. TCF's failure to take into account the side effects and complications of experimental drugs being tested resulted in "the unnecessary deaths" of three other chimpanzees, the USDA charges.

McKinney says the foundation "disagreed" with most of the USDA findings and has responded in documents not yet public.

Also in February, TCF was disciplined by NIH's Office for Protection from Research Risks. The office required, among other things, that TCF hire seven "fully qualified" veterinarians. McKinney says the facility, which also houses 250 monkeys, currently has 4.5 veterinarians on staff. "They are difficult to find. There are not that many veterinarians running around who have experience with non-human primates, and in particular chimps."

The National Institute of Allergy and Infectious Diseases (NIAID) confirmed last week that it had not renewed a $\$ 640,000$, one-year contract that expired on 31 March. Officials would not comment on the reasons. (Between 1993 and 1997, NIAID paid TCF $\$ 3.3$ million in contract costs.)

A six-year, \$5.3 million National Cancer Institute (NCI) contract with TCF expired on 31 December and has not been renewed. During the contract, the number of chimps at TCF supported by NCI fell from 30 to six. "The research that we had wanted to accomplish was finished," says an official. "We never had any problem with the care that the Coulston Foundation gave to our animals."

The foundation is currently receiving $\$ 8.8$ million between 1995 and 2000 from the National Center for Research Resources (NCRR), under its National Chimpanzee Breeding and Research Programme.

IDA claims that this contract will expire or be reduced next year, as the government reduces support for chimpanzee breeding. The NCRR plans to consolidate the five chimp centres it supports to two or three.

Some of TCF's chimps came from New Mexico State University in 1993, and a hundred came from New York University's Laboratory for Experimental Medicine and Surgery in Primates, which closed in 1997 (see Nature 390,321; 1997). Meredith Wadman 